\title{
Impact of Environmental Dynamism on Marketing Strategy Comprehensiveness and Organizational Performance
}

\author{
Wael Mohd, Subhi Idris ${ }^{1} \&$ Raed A. Momani ${ }^{2}$ \\ ${ }^{1}$ Business Administration, Jinan University, The Hashemite Kingdom of Jordan \\ ${ }^{2}$ Marketing-Faculty of Business, Evening Studies Director/University of Petra, The Hashemite Kingdom of \\ Jordan \\ Correspondence: Wael Mohd Subhi Idris, Business Administration, Jinan University, The Hashemite Kingdom \\ of Jordan. E-mail: waelbsc@yahoo.com
}

Received: February 18, 2013

Accepted: March 7, 2013

Online Published: April 14, 2013

doi:10.5539/ijbm.v8n9p40

URL: http://dx.doi.org/10.5539/ijbm.v8n9p40

\begin{abstract}
In highly competitiveness market, companies operate in an intense competitive atmosphere and further globalization of markets, fundamental changes occurred, and forced many companies to rethink and adapt their strategies to search for new philosophies and innovative management techniques to improve their competitive position and performance. The main purpose of this study is to investigate the impact of environmental dynamism on Marketing Strategy Comprehensiveness and Organizational Performance. Environmental dynamism was measured through two dimensions: Intensity of Changes and Frequency of Changes. Comprehensiveness Marketing Strategy was also measured through (5) items. The hypotheses were tested in the domain of Cellular Communications Companies in Jordan. A total of (53) managers and head of section from (60) was answered the questionnaire. Results indicate that environmental dynamism has a significant impact on organizational performance and Comprehensiveness Marketing Strategy, Comprehensiveness Marketing Strategy has significant impact on organizational performance. Results showed that Frequency of Changes is superior impact on organizational performance than Intensity of Changes. To achieve Superior performance, managers and head of section must dealing and managing with cases of environmental dynamism to enhancement organizational performance for their companies.
\end{abstract}

Keywords: environmental dynamism, marketing strategy comprehensiveness, organizational performance and Jordan

\section{Introduction}

Business environment faced rapid transformations had positive and negative effects on the business organizations according to their responsiveness, adaptation and competitiveness capabilities. Through this situation, organizations need to strategic management approach based on managerial philosophies and non-traditional strategies to address environmental dynamism aiming to achieve superior performance via more interest in external environment variables to bring added value for customer, high uniqueness, in another context Interest more on environmental dynamism. Therefore environmental dynamism is a widely-explored construct in organization theory/strategic management literature. It has growing importance according to the degree of instability/turbulence of such key operating concerns as market/industry conditions as well as more general technological, economic, social, political forces. An organization's ability to adapt to changing environmental circumstances is key to survival. The environmental dynamism has to be an essential factor for strategy development and source of profitability. Researchers in the strategic management and organization theory field realized the importance of environmental dynamism to enhance strategy (Luo \& Park, 2001). One stream of research shown that managerial perceptions of the exogenous business environment influence firm strategy which in turn influences firm performance (Verdu-Jover et al. 2006).

Environmental dynamism represents the rate of change in an environment. For example, Wijbenga and van Witteloostuijn (2007) defined environmental dynamism as the rate at which the preferences of consumers and the services of organizations change over time. (Akgün et al. 2008; Gül, 2011) linking environmental dynamism directly with performance. Verdu-Jover et al. (2006) has also been suggested that the resource and capability theory, and competitiveness literatures stressed that perception the external business environment opportunities 
influence organization strategy which in turn influences organizational performance. Therefore, this research will contribute to the awareness of cellular communications companies in Jordan toward the major role to play in Jordanian national economy.

However, since environmental dynamism are vital components in strategy formulation success, therefore, the lack of interest Jordanian cellular communications companies in alignment between environmental dynamism and their strategies weaker levels of satisfaction among its customers. in addition, through the researchers were investigating the studies related to the Environmental Dynamism and the Marketing Strategy Comprehensiveness which was applied in Jordan, they could not find any previous study that has been applied in the Jordanian environment. Since this study and their variables is the first study in Jordan generally, and in the Cellular Communications industry companies specifically.

Based on that, the main aim of this study is to examine the impact of Environmental Dynamism on Marketing Strategy Comprehensiveness and Organizational Performance in Cellular Communications companies in Jordan. The current study focuses on Environmental Dynamism (Intensity of Changes and Frequency of Changes) beside Marketing Strategy Comprehensiveness and organizational performance in Cellular Communications industry companies in Jordan.

\subsection{Study Objectives}

Based on the information stated above, the current research aims to achieve the following:

1) Recognition the impact of Environmental Dynamism on Organizational Performance of Cellular Communications Companies in Jordan.

2) Test the impact of Environmental Dynamism on Marketing Strategy Comprehensiveness of Cellular Communications Companies in Jordan.

3) Examine the impact of Marketing Strategy Comprehensiveness on Organizational Performance of Cellular Communications Companies in Jordan.

\subsection{Significance of the Study}

The business organizations in the Arab countries suffer from a lack of studies that diagnosed interaction between environment variables with administrative environment. The Significance of the current study stems from the following considerations:

1) Highlight the Environmental Dynamism implications that facing organizations in general and Jordanian Cellular Communications Companies In particular and its importance in achieving high levels of performance, which raises the level of performance of Jordanian Cellular Communications Companies and contribute to the achievement of objectives in the long term.

2) Combine between different topics, and diagnosed variables interaction, thus contributing to the development of new and datum concepts.

3) The Current study contributes in unfolding new horizons for other studies that deal with environmental dynamism topic and concerned it, especially in the Jordanian Cellular Communications Companies

4) Fulfilling interest for Jordanian Cellular Communications Companies and their decision-makers and those interested in this industry, also providing recommendations that will contribute in increasing the interest level with the current study variables.

5) Avoid a lack of field studies linking the current study subjects and their variables in the Jordanian content, with making it the first attempt in the Jordanian environment taught this subject, and seek to develop relations and examine its impact.

\section{Theoretical Review}

\subsection{Environmental Dynamism}

Environmental dynamism is a widely-explored construct in the organization theory and strategic management literatures. It refers to the degree of instability or turbulence of such key operating concerns as market and industry conditions as well as more general technological, economic, social, and political forces (Dess and Beard, 1984). Empirically Keats and Hitt (1988) linked Dynamism to organization environment as strategic diversification and organizational "postures" toward innovation (Zahra and Pearce, 1990). These studies and others indicate the importance of the environmental dynamism construct in explaining firm-level phenomena.

Dynamic business environments may be characterized by changes in various market elements, such as customer 
preferences, technology and competitor structure. The terms 'turbulence' and 'volatility' refer to environmental characteristics similar to environmental dynamism and they all are related to the degree and speed of changes (Ansoff, 1979).

Environmental dynamism refers to the rate of change and the level of factors instability within an environment (Li and Simerly, 1998). It could thus be defined with reference to technological change and instability or unpredictability of the environment (Tegarden et al., 2005). Extreme situations of environmental dynamism result in conditions of 'hyper competition', where the benefits derived from almost all form of competitive advantage are short-lived (Bierly and Daly, 2007). Iansity (1995) suggests that emergent levels of environmental dynamism lead to more uncertainty in product development, which also reduces the predictability and effects of change the changes.

\subsection{Marketing Strategy Comprehensiveness}

Marketing strategy is broadly classified into two categories: competitive marketing strategy that aims to deploy resources and capabilities to compete in the market; relationship marketing strategy attempts to deal with networking and alliance resources (Yan and Chew, 2011). While comprehensiveness term recognized as a major characteristics of marketing strategy decision making (Atuahene-Gima \& Murray, 2004).

Market information for strategy making tends to contain tacit components that retard collective interpretation and information sharing. Even when market information is made explicit in a codified routine and communicated to project members, some of them may not understand it because they interpret and apply the knowledge in a different functional and experiential context. Consequently, market information collection, analysis, and interpretation in marketing strategy making for a specific product is a complex process that involves the understanding of multiple functions (Menon et al. 1999).

In this respect, institutional theory implies that managers' external ties serve as conduits for information that shape managerial views about the environment and the strategic choices they make. In support of this theory, Geletkanycz and Hambrick (1997) find that managers' external relationships with other managers within and outside their industry influence their propensity to conform to prevailing organizational strategies. Given the increasing focus on Marketing Strategy Comprehensiveness among marketing managers (Menon et al. 1999), this suggests that employee's ties with managers within and outside the firm's industry are antecedents of MSC.

\subsection{Organizational Performance}

In the literature two types of measures of the firm performance to distinguish: first, financial measures or again objective measures, for example, return on equity, return on sales and return on assets. Second, none financial measures or again subjective measures, for example, shareholders' satisfaction, employee's satisfaction, customers satisfaction (Ong and Teh, 2009). Of fact, operationalization of performance refers to the selection of the appropriate measures when assessing company performance. For instance, Falshaw et al. (2006) have noted that financial measures of performance can capture only one part of the company's profitability. Nonetheless, the mode of performance operationalization is one of the potential methodological causes of the contradictory results of empirical works on the relationship between comprehensiveness and performance (Brock and Barry, 2003). Performance reflection the way of how the organization use and exploited tangible, intangible resources that makes them able to achieve its goals (Wheelen \& Hunger, 2010).

\subsection{Environmental Dynamism, Marketing Strategy Comprehensiveness and Organizational Performance}

Environmental dynamism refers to the extent of unexpected change in organization's environment. Although the strategic management and organization theory literature uses a variety of terms reflecting environmental dynamism such as uncertainty, volatility. All of terms capture to some extent the underlying theme of unexpected change. Gilley (2000) points that there are a variety of relationships between organizational environment and their performance in the literature by cases studying (Gilley, 2000). Homburg et al. (1999) found that top management in organization tends to have a lower impact on performance in dynamic rather than stable environments. In fact, many authors have found empirical support arguing that turbulent and unpredictable environments effected firm's performance (Nadkarni \& Narayanan, 2007). Akgün et al. (2008) confirms that changes in the external environment enhance firm performance. Gül (2011) found that environmental dynamism has an effect on firm performance.

On the other hand, Rajagopalan et al. (1993) conclude that research in strategy should control for the environment. Situation analysis should not only facilitate the understanding and identification of environmental enablers and obstacles to the strategy (Grant, 1995), but also put the firm in the position to identify the most appropriate strategy-operating environment fit. Menon et al. (1999) indicated that a systematic analysis of the 
market context is necessary to align the strategy and the environment. Luo \& Park (2001) emphasis that environmental factors are decisive when organization is determining its strategy. Bamber et al. (2004) argue that organizations develop their strategies based on environment factors. In fact, literature of both strategic management and organization theory showed the firm as a entities affect and are affected by the environment must adapt its strategy based on environmental requirements (Child, 2004). Key argument in the extant literature is that strategy enhances performance because by generating diverse information about the market and competitors environment and by identifying the strengths and weaknesses of several strategic options, the firm is in a better position to implement a strategy more effectively (Menon et al. 1999).

Although there may be good reasons for this argument, there are also significant costs associated with marketing strategy comprehensiveness. Indeed, some scholars have argued that given the cognitive limitations and bounded rationality of decision makers, strategy comprehensiveness is nearly impossible because of the high cost and time-consuming processes of information acquisition and analysis (Bahaee, 1992). These arguments imply that too much or too little marketing strategy comprehensiveness may diminish performance, thus suggesting that it has an effect on performance only at a moderate level. From a contingency theory perspective, this suggests that managers who are able to determine the level of marketing strategy comprehensiveness that reflects their cognitive and other internal resources will derive higher performance from marketing strategy comprehensiveness.

The resource based view theory, and competitive advantage literatures stressed that the perception of external business environment opportunities influence organization strategy which in turn influences organizational performance (Verdu-Jover et al. 2006). As a heuristic for strategy implementation, managers make a sense of the environmental threats and opportunities, calibrate them with internal strengths and weaknesses of the firm, and then engage in a decision process that involves incremental resource investments or divestments whereby they alter the resource base of their firm to co-align with the perceived demands of the new environment (Sirmon et al. 2007; Teece 2007).

\section{Conceptual Framework and Hypotheses}

\subsection{Conceptual Framework}

Figure 1 illustrates the study proposed model which indicated that there are three variables. First, Environmental Dynamism which was considered as independent variable includes two dimensions dimensions: Intensity of Changes and Frequency of Changes These two dimensions were affected on Marketing Strategy Comprehensiveness and organizational performance as the dependents.

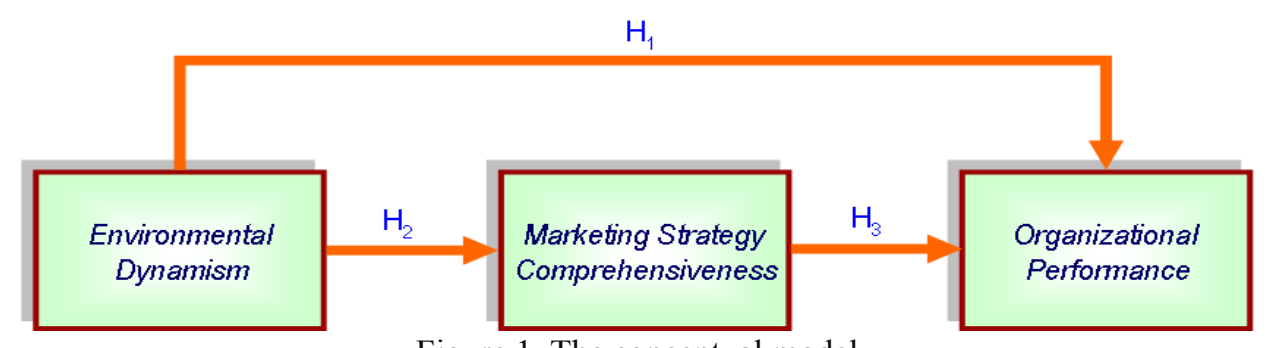

Figure 1. The conceptual model

We suggest that interest in Environmental Dynamism leads to Marketing Strategy Comprehensiveness and Achieve high levels of organizational performance, In addition, the interest in Environmental Dynamism enable of formulate Comprehensiveness Marketing Strategy and higher levels of organizational performance. Then, we propose that Marketing Strategy Comprehensiveness act as a leading cause to organizational performance. For the Cellular Communications Companies in Jordan to maintain Comprehensiveness Marketing Strategy and enhances organizational performance should awareness and sensibility Environmental Dynamism.

\subsection{Research Hypotheses}

Therefore, to investigate the effects between previous variables, the researchers developed three research hypotheses:

$\mathrm{H}_{1}$ : Environmental Dynamism (Intensity of Changes and Frequency of Changes) has a significant impact on Organizational Performance.

H2: Environmental Dynamism (Intensity of Changes and Frequency of Changes) has a significant impact on 
formulate Comprehensiveness Marketing Strategy.

H3: Comprehensiveness Marketing Strategy has a significant impact on Organizational Performance.

\section{Research Methodology}

The current study is empirical and analytical examine the impact of Environmental Dynamism on Jordanian Cellular Communications Companies organizational performance and comprehensiveness Marketing Strategy.

\subsection{Study Population, Sample and Data Collection}

The current study is applied based on the data collected from a population study (of mangers and heads of sections) working in cellular communications companies in Jordan [Zain, Orange and Umniah]. The total population of the study was (60) under the comprehensive survey method. A total of (53) (of the total of 60) managers and heads of section answered the distributed questionnaire. A great majority of the study sample was male, at a percentage of $77.4 \%$, where $50.9 \%$ of them were between the ages of 30 and 30 years and $47.1 \%$ having reasonably well-established experience of 6-10 years.

\subsection{Analysis of Data}

The data collected from the responses was treated through SPSS "Statistical Package for Social Sciences" in two stages. First, descriptive analysis through mean, standard deviation and one sample t-teat of underlying study variables Environmental Dynamism, Comprehensiveness Marketing Strategy, organizational performance. Second, analytical through multiple and simple regression analysis to understand the effects between study variables.

\subsection{Measurement and Scale}

To achieve study objectives required developing a scale for the study variables "Environmental Dynamism, Comprehensiveness Marketing Strategy and organizational performance". After conducting a survey on the available measurements for measuring environmental dynamism we have depend on the scale developed by Volberda \& Van Bruggen (1997) in a five Likert scale (" 1 " Do not agree to "5" Agree completely). We identified Environmental Dynamism as independent variable consisting two dimensions and (7) items: ("3" items for intensity of changes and "4" items for frequency of changes). The results of environmental dynamism descriptive analysis explain in tables 1 and 2.

As shown in tables 1 and 2. The general mean scores (4.17) for Intensity of Changes and (3.49) for Frequency of Changes on (5) likert measurement which indicate taunt level of the Intensity of Changes and median level of the Frequency of Changes facing Cellular Communications Companies in Jordan.

Table 1. Descriptive statistics of environmental dynamism (intensity of changes)

\begin{tabular}{clcc}
\hline No. & \multicolumn{1}{c}{ Intensity of Changes } & $\begin{array}{c}\text { Arithmetic } \\
\text { Mean }\end{array}$ & $\begin{array}{c}\text { Standard } \\
\text { Deviation }\end{array}$ \\
\hline 1 & Changes in our market very intense & 4.32 & 0.83 \\
2 & Our customers regularly ask for complete new services & 4.17 & 0.91 \\
3 & Our market can be characterized by more of the same & 4.02 & 0.97 \\
& & 4.17 & 0.85 \\
\hline
\end{tabular}

Table 2. Descriptive statistics of environmental dynamism (frequency of changes)

\begin{tabular}{|c|c|c|c|}
\hline No. & Frequency of Changes & $\begin{array}{c}\text { Arithmetic } \\
\text { Mean }\end{array}$ & $\begin{array}{c}\text { Standard } \\
\text { Deviation }\end{array}$ \\
\hline 4 & In our market changes are taking place continuously & 3.49 & 0.93 \\
\hline 5 & Within a year nothing will have changed in our market & 3.47 & 0.99 \\
\hline 6 & Our supply of services changes continuously & 3.60 & 0.84 \\
\hline 7 & $\begin{array}{l}\text { In our market the volumes of services to be delivered change } \\
\text { fast and often }\end{array}$ & 3.40 & 1.01 \\
\hline & Total & 3.49 & 0.82 \\
\hline
\end{tabular}


For Comprehensiveness Marketing Strategy variable. The researcher uses scale developed by Atuahene-Gima and Murray (2004) in a five Likert-scale ("1" Do not agree to "5" Agree completely). The Comprehensiveness Marketing Strategy variable descriptive analysis presented in table 3. As shown in table 3, the general mean scores (3.51) which indicate median level of Comprehensiveness Marketing Strategy adapting from Cellular Communications Companies in Jordan.

Table 3. Descriptive statistics of comprehensiveness marketing strategy

\begin{tabular}{|c|c|c|c|}
\hline No. & Comprehensiveness Marketing Strategy & $\begin{array}{l}\text { Arithmetic } \\
\text { Mean }\end{array}$ & Standard Deviation \\
\hline 8 & $\begin{array}{l}\text { Our managers develop many alternative courses of action to } \\
\text { achieve the intended objectives }\end{array}$ & 3.51 & 1.01 \\
\hline 9 & $\begin{array}{l}\text { Our managers conduct multiple examinations of any suggested } \\
\text { course of action they wanted to take }\end{array}$ & 3.49 & 1.17 \\
\hline 10 & $\begin{array}{l}\text { Our managers Thoroughly examine multiple explanations for } \\
\text { the problems faced and for the opportunities available }\end{array}$ & 3.74 & 0.71 \\
\hline 11 & $\begin{array}{l}\text { Our managers Search extensively for possible alternative } \\
\text { courses of action to take } \\
\text { advantage of the opportunities }\end{array}$ & 3.45 & 0.89 \\
\hline 12 & $\begin{array}{l}\text { Our managers Consider many different criteria before deciding } \\
\text { on which possible courses of action to take to } \\
\text { achieve your intended objectives }\end{array}$ & 3.34 & 0.88 \\
\hline & Total & 3.51 & 0.73 \\
\hline
\end{tabular}

In measuring organizational performance variable. The researcher adapting scale suggested by Moore and Fairhurst (2003) through (4) items in (5) Likert measurement from ("1" very low to "5" very high). Organizational Performance variable descriptive analysis presented in table 4.

Table 4. Descriptive analysis of organizational performance variable

\begin{tabular}{cccc}
\hline No. & Organizational Performance & $\begin{array}{c}\text { Arithmetic } \\
\text { Mean }\end{array}$ & Standard Deviation \\
\hline 13 & The sales growth relative to competitor is & 3.58 & 0.75 \\
14 & The market share relative to competitor are & 3.34 & 0.81 \\
15 & The return on investment position relative to competition is & 3.42 & 0.84 \\
16 & The net profit relative to competitor is & 3.09 & 1.06 \\
& Total & 3.36 & 0.69 \\
\hline
\end{tabular}

As shown in table 4, the general mean scores (3.36) on five likert scale which indicate median level of Organizational Performance in Cellular Communications Companies in Jordan.

\subsection{Reliability Measure}

The reliability analysis applied to the level of Cronbach Alpha $(\alpha)$ is the criteria for internal consistency, which was at a minimum acceptable level (Alpha $\geq 0.60$ ). Table 5 illustrative the consistency for study variables. 
Table 5. Reliability analysis of environmental dynamism, comprehensiveness marketing strategy and organizational performance

\begin{tabular}{cccc}
\hline Variables & Dimensions & No of Items & Cronbach alpha \\
\hline & Intensity of Changes & 3 & 0.727 \\
Environmental Dynamism & Frequency of Changes & 4 & 0.779 \\
& - & 5 & 0.826 \\
Comprehensiveness Marketing Strategy & - & 4 & 0.745 \\
Organizational Performance & & 16 & 0.889 \\
Overall Questionnaire & &
\end{tabular}

As shown in table 5 Cronbach alpha reliability are acceptable levels. The overall Cronbach alpha of questionnaire is (0.889). Sekaran (2003) indicated (0.60) to be an acceptable reliability coefficient.

\section{Study Analytical Results}

\subsection{Hypotheses Testing}

Through using multiple and simple regressions analysis, significant effects were found between Environmental Dynamism, Comprehensiveness Marketing Strategy and organizational performance.

$\mathbf{H}_{\mathbf{1}}$ : Environmental Dynamism (Intensity of Changes and Frequency of Changes) has a significant impact on Organizational Performance.

To examine the first hypothesis, multiple regression analysis was uses by considering Organizational Performance as the respondent variable, and the two dimensions of Environmental Dynamism: Intensity of Changes and Frequency of Changes as independent variables. Table 6 illustrates the multiple regression results analysis.

Table 6. Summary of multiple regression results-impact of environmental dynamism (intensity of changes and frequency of changes) on organizational performance cellular communications companies in Jordan

\begin{tabular}{|c|c|c|c|c|c|c|c|c|c|}
\hline \multirow[t]{2}{*}{$R$} & \multirow[t]{2}{*}{$\mathrm{R}^{2}$} & \multirow{2}{*}{$\begin{array}{c}\text { F } \\
\text { Calculate }\end{array}$} & \multicolumn{2}{|c|}{ Degree of Freedom } & \multirow[t]{2}{*}{ Sig* } & \multirow[t]{2}{*}{$\beta$} & & \multirow{2}{*}{$\begin{array}{c}\mathrm{T} \\
\text { Calculate }\end{array}$} & \multirow[t]{2}{*}{ Sig* } \\
\hline & & & & & & & & & \\
\hline \multirow[t]{4}{*}{0.598} & 0.357 & 13.894 & Regression & 2 & 0.000 & Intensity & 0.409 & 2.288 & 0.026 \\
\hline & & & Residual & 50 & & & & & \\
\hline & & & & & & Frequency & 0.816 & 4.403 & 0.000 \\
\hline & & & Total & 52 & & & & & \\
\hline
\end{tabular}

Table 6 illustrates that Environmental Dynamism (Intensity of Changes and Frequency of Changes) has a significant impact on Organizational Performance. The regression model showed a high level of fit, as reflected by " $R$ " and " $R$ " value $(0.598),(0.357)$, which asserted that $(0.357)$ of the explained variation in organizational performance can be accounted for Environmental Dynamism (Intensity of Changes and Frequency of Changes). On the other hand, the table 6 for the executive data set indicated the slope value of $(0.409),(0.816)$ for the regression line. This suggested that for a one unit increase in Environmental Dynamism (Intensity of Changes and Frequency of Changes) the respective organization can significantly predict a $(0.409),(0.816)$ increase in organizational performance. As well as table 6 shows that the analysis of variance of the fitted regression equation is significant with $\mathrm{F}$ value of (13.894). This is an indication that the model is a good one. Since the p-value is less than (0.05), it shows a statistically significant relationship between the variables at $(0.95)$ confidence level. The results also indicate that Environmental Dynamism (Intensity of Changes and Frequency of Changes) actually impact the Organizational performance of Cellular Communications Companies in Jordan with a coefficient of (0.409) for Intensity of Changes and (0.816) for Frequency of Changes. Therefore, the alternative hypothesis of a significant impact is accepted. Thus, Environmental Dynamism (Intensity of Changes and Frequency of Changes) has a significant impact on Cellular Communications Companies in Jordan organizational performance. This further supported the study first hypothesis.

H2: Environmental Dynamism (Intensity of Changes and Frequency of Changes) has a significant impact on formulate Comprehensiveness Marketing Strategy.

To examine the second hypothesis, multiple regression analysis was uses by considering the comprehensiveness 
Marketing Strategy as the respondent variable, and the two dimensions of Environmental Dynamism: Intensity of Changes and Frequency of Changes as the Independent variables. Table 7 illustrates the multiple regression analysis.

Table 7. Summary of multiple regression results-impact of environmental dynamism (intensity of changes and frequency of changes) on comprehensiveness marketing strategy cellular communications companies in Jordan

\begin{tabular}{|c|c|c|c|c|c|c|c|c|c|}
\hline$R$ & $\mathrm{R}^{2}$ & F Calculate & \multicolumn{2}{|c|}{ Degree of Freedom } & Sig* & \multicolumn{2}{|c|}{$\beta$} & T Calculate & Sig* \\
\hline \multirow[t]{4}{*}{0.762} & 0.580 & 34.578 & Regression & 2 & 0.000 & Intensity & 0.461 & 4.802 & 0.000 \\
\hline & & & Residual & 50 & & & & & \\
\hline & & & & & & Frequency & 0.895 & 5.683 & 0.000 \\
\hline & & & Total & 52 & & & & & \\
\hline
\end{tabular}

H3: Comprehensiveness Marketing Strategy has a significant impact on Organizational Performance.

To examine third hypothesis, simple regression analysis was uses by considering the Organizational Performance as the respondent variable, and the Comprehensiveness Marketing Strategy as the Independent variable. Table 8 illustrates the simple regression results of the variables.

Table 8. Summary of simple regression results-impact of comprehensiveness marketing strategy on organizational performance cellular communications companies in Jordan

\begin{tabular}{|c|c|c|c|c|c|c|c|c|}
\hline \multirow[t]{2}{*}{$R$} & \multirow[t]{2}{*}{$\mathrm{R}^{2}$} & \multirow{2}{*}{$\begin{array}{c}\text { F } \\
\text { Calculate }\end{array}$} & \multicolumn{2}{|c|}{ Degree of Freedom } & \multirow[t]{2}{*}{ Sig* } & \multirow[t]{2}{*}{$\beta$} & \multirow{2}{*}{$\begin{array}{c}\mathrm{T} \\
\text { Calculate }\end{array}$} & \multirow[t]{2}{*}{ Sig* } \\
\hline & & & & & & & & \\
\hline \multirow[t]{3}{*}{0.768} & 0.590 & 73.437 & Regression & 1 & 0.000 & 0.731 & 8.569 & 0.000 \\
\hline & & & Residual & 51 & & & & \\
\hline & & & Total & 52 & & & & \\
\hline
\end{tabular}

Table 8 shows that Comprehensiveness Marketing Strategy has a significant impact on Organizational Performance. The regression model showed a high level of fit, as reflected by " $R$ " and " $R$ " "value $(0.768)$, (0.590), which asserted that (0.590) of the explained variation in Organizational Performance can be accounted for Comprehensiveness Marketing Strategy. On the other hand, the table 8 for the executive data set indicated the slope value of (0.731) for the regression line. This suggested that for a one unit increase in Comprehensiveness Marketing Strategy the respective organization can significantly predict a $(0.731)$ increase in Organizational Performance. As well as table 8 shows that the analysis of variance of the fitted regression equation is significant with $F$ value of (73.437). This is an indication that the model is a good one. Since the p-value is less than (0.05), it shows a statistically significant relationship between the variables at (0.95) confidence level. The results also indicate that Comprehensiveness Marketing Strategy actually impact the Organizational Performance of Cellular Communications Companies in Jordan with a coefficient of (0.731). Therefore, the alternative hypothesis of a significant impact is accepted. Thus, Comprehensiveness Marketing Strategy has a significant impact on Organizational Performance in Cellular Communications Companies in Jordan. This further supported the study third hypothesis.

\section{Conclusions and Implications}

This current study provides an applied examining of the impact Environmental Dynamism on Organizational Performance and Marketing Strategy Comprehensiveness. The Environmental Dynamism considers as a primary factor of Marketing Strategy Comprehensiveness formulation and organizational performance. The empirical study shows that Environmental Dynamism (Intensity of Changes and Frequency of Changes) were significant impact on organizational performance.

These results meet with Akgün et al. (2008) and Gül (2011) results. Furthermore, the two dimensions of Environmental Dynamism are significant impact Marketing Strategy Comprehensiveness meeting with Luo and Park (2001); Bamber et al. (2004) and (Child, 2004) finding which argued Environmental Dynamism are key component in enhancing the Marketing Strategy Comprehensiveness. Therefore, strategy comprehensiveness enhances performance. 
The regression analyses results support the current study hypothesis. Consistent with $\mathrm{H}_{1}$, that Environmental Dynamism (Intensity of Changes and Frequency of Changes) has a significant impact on Organizational Performance. Respecting with $\mathrm{H}_{2}$, the Environmental Dynamism (Intensity of Changes and Frequency of Changes) has a significant impact of on Marketing Strategy Comprehensiveness. For $\mathrm{H}_{3}$ that Marketing Strategy Comprehensiveness has a significant impact on organizational performance. The current study gives an applied guide of the Impact of Environmental Dynamism on Marketing Strategy Comprehensiveness and Organizational Performance. Based on the above, Cellular Communications Companies in Jordan managers and head of section can benefits from current results to reformulation comprehensiveness marketing Strategy that will help to achieving excellence and enhancing organizational performance. To achieve Superior performance and hold organizational Excellence, managers and head of section must dealing and managing with cases of environmental dynamism to enhancement organizational performance for their companies. In addition, Cellular Communications Companies in Jordan must provision some flexibility in the completion of the tasks in light controls accuracy and objectivity at the same time to provide different types of means to implementing the tasks. Finally, Cellular Communications Companies in Jordan must conduct continuous surveys to get feedback from customers and their preferences about the services offered, levels and prices and their suitability to the customers needs and wishes, especially the expected (future).

\section{References}

Akgün, A. E., Keskin, H., \& Byrne, J. (2008). The moderating role of environmental dynamism between firm emotional capability and performance. Journal of Organizational Change Management, 21(2), 230-252. http://dx.doi.org/10.1108/09534810810856453

Ansoff, H. (1979). Strategic Management. London: The McMillan Press Ltd.

Atuahene-Gima, K., \& Murray, J. Y. (2004). Antecedents and Outcomes of Marketing Strategy Comprehensiveness. Journal of Marketing, 68, 33-46. http://dx.doi.org/10.1509/jmkg.68.4.33.42732

Bahaee, M. (1992). Strategy-Comprehensiveness Fit and Performance. Australian Journal of Management, 17(2), 195-216. http://dx.doi.org/10.1177/031289629301700202

Bamber, G. J., Lansbury, R. D., \& Wailes, N. (2004). Introduction. In Bamber, G. J., Lansbury, R. D., \& Wailes, N. (Eds.), International and Comparative Employment Relations: Globalization and the Developed Market Economies. Sydney: Allen and Unwin.

Bierly, P. E., \& Daly, P. S. (2007). Alternative knowledge strategies, competitive environment, and organizational performance in small manufacturing firms. Entrepreneurship Theory and Practice, 31, 493-516. http://dx.doi.org/10.1111/j.1540-6520.2007.00185.x

Brock, D. M., \& Barry, D. (2003). What if planning were really strategic? Exploring the strategy-planning relationship in multinationals. International Business Review, 12, 543-561. http://dx.doi.org/10.1016/S0969-5931(03)00075-1

Child, J. (2004). Organizational structure, environment and performance: the role of strategic choice. Sociology, 6, 1-22. http://dx.doi.org/10.1177/003803857200600101

Dess, G. G., \& Beard, D. W. (1984). Dimensions of organizational task environments. Administrative Science Quarterly, 29, 52-73. http://dx.doi.org/10.2307/2393080

Falshaw, J. R., Glaister, K. W., \& Tatoglu, E. (2006). Evidence on formal strategic planning and company performance. Management Decision, 44(1), 9-30. http://dx.doi.org/10.1108/00251740610641436

Geletkanycz, M. A., \& Donald, C. H. (1997). The External Ties of Top Executives: Implications for Strategic Choice and Performance. Administrative Science Quarterly, 42(4), 654-681. http://dx.doi.org/10.2307/2393653

Gilley, M. K. (2000). Making More by doing less: An analysis of outsourcing and its effects on firm performance. Journal of Management, 26, 763-790.

Grant, R. (1995). Contetnporary Strategy Analysis. Cambridge. MA: Biackwell Publishers.

Gül, M. C. (2011). Environmental Dynamism, Innovativeness and Firm Performance. The 2011 Las Vegas International Academic Conference. Las Vegas, Nevada.

Homburg, C., Krohmer, H., \& Workman, J. P. (1999). Strategic consensus and performance: the role of strategy type and market-related dynamism. Strategic Management Journal, 20, 339-357. http://dx.doi.org/10.1002/(SICI)1097-0266(199904)20:4<339::AID-SMJ29>3.0.CO;2-T 
Iansity, M. (1995). Shooting the rapids: managing product development in turbulent environments. California Management Review, 38, 37-58. http://dx.doi.org/10.2307/41165820

Keats, B. W., \& Hitt, M. A. (1988). A causal model of linkages among environmental dimensions, macro organizational characteristics and performance. Academy of Management Journal, 31, 570-598. http://dx.doi.org/10.2307/256460

Li, M., \& Simerly, R. L. (1998). The moderating effect of environmental dynamism on the ownership and

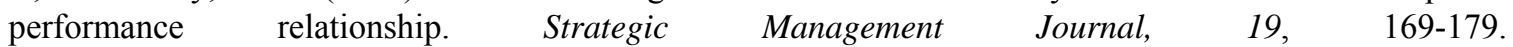
http://dx.doi.org/10.1002/(SICI)1097-0266(199802)19:2<169::AID-SMJ939>3.0.CO;2-2

Luo, Y., \& Park, S. H. (2001). Strategic alignment and performance of market-seeking MNCs in China. $\begin{array}{llll}\text { Strategic Management } & \text { Journal, } & \text { 141-155. }\end{array}$ http://dx.doi.org/10.1002/1097-0266(200101)22:2<141::AID-SMJ151>3.0.CO;2-O

Menon, A., Phani, T. A., \& Steven, W. E. (1999). Antecedents and Consequences of Marketing Strategy Making: A Model and a Test. Journal of Marketing, 63, 18-40. http://dx.doi.org/10.2307/1251943

Moore, M., \& Fairhurst, A. (2003). Marketing Capabilities and Firm Performance in fashion retailing. Journal of Fashion Marketing and Management, 7(4), 386-397. http://dx.doi.org/10.1108/13612020310496976

Nadkarni, S., \& Narayanan, V. K. (2007). Strategic Schemas, Strategic Flexibility, and Firm Performance: The Moderating Role of Industry Clockspeed. Strategic Management Journal, 28, 243-270. http://dx.doi.org/10.1002/smj.576

Ong, T. S., \& The, B. H. (2009). The Use of Financial and Non-Financial Performance Measures in the Malaysian Manufacturing Companies. Journal of Accounting Research, 1, 23-30.

Rajagopalan, N., Abdul, M. A., \& Deepak, K. D. (1993). Strategic Decision Processes: Critical Review and Future Directions. Journal of Management, 19, 349-384.

Sekaran, U. (2003). Research Methods for Business. John Wiley \& Sons.

Sirmon, D. G., Hitt, M. A., \& Ireland, R. D. (2007). Managing Firm Resources in Dynamic Environments to Create Value: Looking Inside the Black Box. Academy of Management Review, 32(1), 273-292. http://dx.doi.org/10.5465/AMR.2007.23466005

Teece, D. J. (2007). Explicating Dynamic Capabilities: The Nature and Micro-foundations of (Sustainable), Enterprise Performance. Strategic Management Journal, 28, 1319-1350. http://dx.doi.org/10.1002/smj.640

Tegarden, L. F., Sarason, Y., Childers, J. S., \& Hatfield, D. E. (2005). The Engagement of employees in the strategy process and firm performance: The role of strategic goals and environment. Journal of Business Strategies, 22(2), 75-99.

Verdu-Jover, A. J., Llorens-Montes, F. J., \& Garcia-Morales, V. J. (2006). Environment-flexibility Co alignment and Performance: An Analysis in Large versus Small Firms. Journal of Small Business Management, 44(3), 334-349. http://dx.doi.org/10.1111/j.1540-627X.2006.00175.x

Volberda, H. W., \& Van Bruggen, G. H. (1997). Environmental turbulence: A Look into its dimensionality. NOBO-Onderzoekdag, 137-145.

Wheelen, T., \& Hunger, D. (2010). Strategic Management and Business Policy (13th ed.). Pearson: Prentice Hall, Upper Saddle River, U.S.A.

Wijbenga, F. H., \& Van, Witteloostuijn, A. (2007). Entrepreneurial locus of control and competitive strategies: The moderating effect of environmental dynamism. Journal of Economic Psychology, 28, 566-589. http://dx.doi.org/10.1016/j.joep.2007.04.003

Yan, S. G., \& David, A. S. (2011). An investigation of marketing strategy, business environment and performance of construction SMEs in China. African Journal of Business Management, 5(6), 2396-2405.

Zahra, S. A., \& Pearce, I. A. (1990). Research evidence on the Miles-Snow typology. Journal of Management, 16, 751-768. http://dx.doi.org/10.1177/014920639001600407 